\title{
MIGHT THE MUSEOLOGY BE A PART OF NEUROSCIENCES?

\section{ABSTRACT/ABSTRAKT}

The 1990s as well as the first decade after the year 2000 have brought numerous attempts of revisiting the fundamental questions related to the reasons for creating art, and the way museums use art for visualizing and planning exhibitions. The real support in these researches was found among neurocognitivists, who, like prof. Semir Zeki, analysed human brain' activity in museums context. This article reports how neuroesthetic was born and developing through art experience, and how museums have been changing when faced with these new approaches. What was noticed by John Onians in his Neuroarthistory, that "neuroscience also made it not just possible, but necessary, to bring back together things long treated as separate - the mind and the body, the sensory system and the motor system, cognition and the viscera" - changed practice in contemporary museums. Conclusion of this text is that the process of "museologising" of the world, we perceive nowadays as a global phenomena, has roots in neuroesthetic experience, transferring visitors to a tangible and multi-sensual world, quite different then virtual and digital everyday practice.

\section{Mohla by muzeologie být součás-} tí neurovědy?

90. léta 20. století i první desetiletí století následujícího přinesly četné pokusy o revizi základních otázek týkajících se důvodů vzniku umělecké tvorby a způsobu, jakým muzea využívají umění $\mathrm{k}$ vizualiza- ci a plánování výstav. K těmto výzkumům významnou měrou přispěli kognitivní neurovědci, např. prof. Semir Zeki, kteř́ zkoumali aktivitu lidského mozku v muzejním kontextu. Tento článek pojednává o vzniku a vývoji neuroestetiky skrze uměleckou zkušenost a také o tom, jakým způsobem se muzea měnila v konfrontaci s těmito novými př́stupy. Soudobá muzejní praxe je výsledkem proměny, o které se zmiňuje John Onians ve svém díle Neuroarthistory: „neurověda nejen umožnila, nýbrž si př́mo vynutila opětovné spojení věcí, které byly dlouhou dobu vnímány jako oddělené - mysl a tělo, smyslové orgány a pohybový aparát, poznání a vnitřní orgány." V závěru tohoto textu se uvádí, že proces „muzeologizace“ světa, který v současnosti vnímáme jako globální fenomén, má své kořeny v neuroestetickém zážitku přenášejícím návštěvníky do hmotného a mnohasmyslového světa, jenž je zcela odlišný od virtuální a digitální každodennosti.

\section{KEYWORDS/KLIÍČOVÁ SLOVA}

museum - museology - neurosciences - neuroaesthetic - neuromuseology museum - muzeologie - neurovědy neuroestetika - neuromuzeologie

The 1990s as well as the first decade after the year 2000 have brought numerous attempts of revisiting the fundamental questions related to the reasons for creating art (why do we need art?), the need for its conservation (what are collections for?), and acquisition (why do we need museums?). These questions also address the need for a re-examination of historical works of art and - imbued with thought their composition and comparison to the reflections forming today. These questions, however, come not only from estheticians, art historians, philosophers, anthropologists and culture experts. The circle of those interested in the mechanisms of the influence of art has expanded and now also includes neurocognitivists: neurologists, doctors, physicists, chemists, and psychologists of perception.

The last twenty years have also seen great changes in museology. The study of museums, and their establishment, activities, educational methods, and influence on the identity of different social groups - has been gradually expanding beyond the traditional boundaries of museology - a practice which includes activities in all domains of human and natural activity encompassed in collections and presented for the pleasure of experiencing. "Museologisation"1 of life and its surroundchanging point of analyzes in museum studies. To compare different attitudes in reaserch, see: BOUQUET, Mary (ed.). Academic Anthropoly and the Museum. Back to the Future. Oxford, New York: Berghahn Books, 2001; BOUQUET, Mary. Museums. A Visual Anthropology. London, New York: Berg, 2012; CRANE, Susan A. Museums and Memory. Stanford: Stanford University Press, 2000; CRIMP, Douglas. On the Museum's Ruins. Cambridge: MA, 1993; FOLGA-JANUSZEWSKA, Dorota. The Brain in the Museum. In SZMELTER, Iwona (ed.). Innovative Approaches to the Complex Care of Contemporary Art. Warsaw, London: Archetype Publications, 2012, pp. 66-73; GRENIER, Catherine. La fin des musées? Paris: Editions du Regard, 2013; M. Henning, Museums, Media and Cultural Theory, Maidenhead, OUP, 2006; MALRAUX, André. Le Musée imaginaire. Paris: Galimard, 1947; MESSAGE, Kylie. New Museums and the Making Culture. Oxford, New York: Berg, 2006; CARBONELL, Bettina Messias. (ed.). Museum 
ings has surpassed its limits at the turn of the $20^{\text {th }}$ and $21^{\text {st }}$ centuries: in addition to traditional collections of art, souvenirs, artefacts of nature and the universe, objects from the history of sciences, and literary or musical works, it has created standards and frameworks for "museologising" the virtual world - along with intangible legacy (such as word of mouth). Recently, "museologisation" has begun to created artistic events dedicated directly to museums. Museums are transforming from heterotopia into autotopia right in front of our eyes. ${ }^{2}$

The processes of ammassing intangible legacy and creating virtual collections has turned museologists into directors and set designers. It is becoming increasingly more frequent nowadays to see institutions being established for whom it is not the collection of "objects" that is assembled in time which becomes its focal point. On the contrary, what is at its heart is a certain script which creates a visual perspective of a given event which often entirely forsakes historic documents. Was Walt Disney the harbinger of this phenomenon? Maybe so. The animation, enjoyment and the visual fulfillment of dreams or tales have set in motion boldness to transform reality.

Studies. An Anthology of Contexts. 2nd ed. Chich ester: Wiley-Blackwell, 2012; KOWALSKA, E. and E. URBANIAK (eds.). Muzeum XXI wieku. Teoria i praxis. Materiały z sesji naukowej, organizowane przez Muzeum Początków Państwa Polskiego i Polski Komitet Narodowy ICOM, Gniezno, 25-27 listopada 2009 roku. Ksiega pamiatkowa poświęcona profe sorowi Krzysztofowi Pomianowi [online]. Gniezno: Muzeum Początków Państwa Polskiego, 2010 [cit. 2016-05-15]. Available from www: <http:// www.muzeumgniezno.pl/fotki/files/files/publikacje/muzeum21w.pdf>; MAIRESSE, François. Le Musée, temple spectaculaire. Une histoire du projet muséal. Lyon: Pul, 2003; VERGO, Peter (ed.). The New Museology. London: Reaktion Books, 1989.

2 This is a reference to Michel Foucault's concept of heterotopia - an alternative space juxtaposed to reality, which is tranformed into an area of counter activity - autotopia - areas of strong identity and autonomy interacting with external reality which adopts museological strategies. See: BELTING, Hans. Place of reflection or place of sensation? In NOEVER, Peter (ed.). The Discursive Museum. Vienna: MAK, 2001, pp.77-78.
It is not easy to follow this path of evolution. For the past 2500 years, philosophy, art and literature followed very distinct paths. Despite the closeness of the arts and sciences, generations of people have worked to mark their individuality and unique theoretical approaches. Why, then, do these idiosyncrasies undergo a renewed integration before us? Maybe it is because of the questions asked again by neuro-ophthalmologists and owing to the implementation of their remarks by theorists, historians and estethicians.

A breakthrough in the "different" way of perceiving the role of artistic artefacts in life and in the learning process was initiated by a series of works connected with the psychology of art which culminated in the publication of The Sense of Order. A Study in Psychology of Decorative Art $^{3}$ by Ernst H. Gombrich in 1979. Already back then were Gombrich's students creating works which attracted attention to a particular biological conditioning of the brain on account of which there exists the potential for observing, understanding and for emotional participation in and perception of art. Michael Baxandall published Painting and Experience in Fifteenth-Century Italy: A Primer in the Social History of Style $e^{4}$ in 1972, while in 1978, D. M. Collins and John Onians, in The Origins of Art, ${ }^{5}$ clearly indicated an influence of a neuronal structure in the receptive areas of the brain on the way people react to pictures. An exhibition entitled Perspective. Illusion. Illusionism ${ }^{6}$ was organized

\footnotetext{
3 GOMBRICH, Ernst H. The Sense of Order. A Study in Psychology of Decorative Art. Ithaca: Cornell University Press, 1979.

4 BAXANDALL, Michael. Painting and Experience in Fifteenth-Century Italy: A Primer in the Social History of Style. Oxford: Oxford Paperbacks, 1979.

5 COLLINS, Desmond M. and John ONIANS. The Origins of Art. Art History, 1978, vol. I, pp. 1-25.

6 FOLGA-JANUSZEWSKA, Dorota. Perspective, Illusion, Illusionism: Exhibition Catalogue. Warsaw Muzeum Narodowe w Warszawie/National Museum in Warsaw, 1981.
}

in 1981 at the National Museum in Warsaw - its script reflected the account created in Gombrich's circle of the influence of works of art on the shaping of our visual experiences, on the development of aesthetic sensitivity, as well on the process of understanding or the process of the inability to recognize the set of phenomena called illusionism in art between the $15^{\text {th }}$ and $20^{\text {th }}$ centuries. Shortly thereafter, a related concept was transferred into the domain of $20^{\text {th }}$ century art, namely the Concepts of Space in Contemporary art (Pol. Koncepcje przestrzeni $w$ sztuce wspótczesnej) $)^{7}$ exhibition - which, in the form of a museum exhibition, presented the changes which took place in the last century: as a result of the influence of new concepts in physics and mathematics (including Einstein's theory of relativity and the advancement of quantum physics) artists also began to embrace in their visual projects theoretical phenomena which - on a symbolic level - generated another, non-physical comprehension of the concepts of space and time. Both Warsaw exhibitions were visited by Professor Bogusław Żernicki who was conducting research into the neurophysiology of perception at the Polish Academy of Sciences Institute of Experimental Biology in Warsaw. He drew interesting conclusions which clearly indicated the fact that the role of art is not limited to aesthetic delight nor is a transmission of certain coded meanings but has an enormous formative influence on the evolution of the brain and the way a person interacts with the surrounding world inasmuch as it also stimulates reactions which themselves do not occur in the material world.

The 1970s and 1980s were a time period when research on the functioning of brain structures was

\footnotetext{
7 FOLGA-JANUSZEWSKA, Dorota. Concepts of Space in Contemporary Art: Exhibition Catalogue. Warsaw: Muzeum Narodowe w Warszawie/National Museum in Warsaw, 1984.
} 
evolving intensively, while the results of these studies were included in clearly written and appealingly illustrated publications. ${ }^{8}$ This contributed to this type of information reaching a wider audience - hence also the circles of art historians, aestheticians and philosophers. In 1989, Patricia Smith Churchland entitled her book Neurophilosophy: Toward a Unified Science of the Mind ${ }^{9}$ thus formulating the hitherto prevailing observations. The ball started rolling - and as of that moment, nearly each traditional field received the neuro- prefix. The fields of neuraesthetics and neuromusicology appeared as separate authorized fields.

Studies conducted in the 1960s were revisited and reflected upon. The classics of this field encompassed the deliberations of Rudolph Arnheim ${ }^{10}$ and the early works of Ernst H. Gombrich. Jean-Paul Changeux proposed an analysis of paintings from the perspective of neurosciences. The Lamentation of Christ by Jacquesa Bellange served the purpose of discovering the mechanism of "mirror neurons", which occur solely while perceiving paintings. ${ }^{11}$ Neuroaesthetics became a fast-developing field in the 1990s. Semir Zeki's Inner Vision, An Exploration of Art and the Brain ${ }^{12}$ as well as the article, The Science of Art: A Neurological Theory of Aesthetic

8 The most important ones include: CHANGEUX, Jean-Pierre. L'homme neuronal. Paris: Fayard, 1983; BLAKEMORE, Colin. The Mind Machine. London: BBC Books, 1988; VARELA, Francisco, Evan THOMPSON and Eleonor ROSCH. The Embodied Mind: Cognitive Science and Human Experience. Cambridge: MIT Press, 1991.

9 SMITH CHURCHLAND, Patricia. Neurophilosophy: Toward a Unified Science of the Mind. Cambridge: Bradford Book, 1989.

10 ARNHEIM, Rudolf. Art and Visual Perception: A Psychology of the Creative Eye. Berkeley, Los Angeles, 1954; and ARNHEIM, Rudolf. Visual Thinking. Berkeley: University Of California Press, 1969.

11 CHANGEUX, Jean-Paul. Art and Neuroscience. Leonardo, 1994, vol. 27, no. 3, pp. 189-201.

12 ZEKI, Semir. Inner Vision. An Exploration of Art and the Brain. Oxford: Oxford University Press, 1999.
Experience $^{13}$ written by Ramachandran and Hirstein gave rise to a wave of new studies.

These studies were accompanied by great changes that were taking place in practicing art history and aesthetics which, in turn, were the result of the technological invasion of new transmission methods. The former static or dynamic picture (for instance, a film) being nevertheless just a "single and closed" picture (its creator chose its frame, or the beginning or end of its exposure) - started changing: in a quite simple way it began to be superimposed onto other frames, images, or symbols (for example, the transparency of television symbols applied over transmissions from all over the world, or the montage and application of "transparent" frames), which led to an obliteration of or fading of the borders between them. Gradually, the study of "pictures", which until then were of interest to art historians, turned into studies of "visual events", while their effects and field of study became known as the study of visual culture. ${ }^{14}$

Neurosciences had undoubtedly contributed to this change. By searching for mechanisms of visual communication and paying attention to the kinetic aspect of the arts, ${ }^{15}$ many authors noticed an increasingly greater number of relationships between visual perception as a neuronal process and consciousness thus far treated as a "higher" level of knowledge and cognition. At some point, the famous discussion - known as the

\footnotetext{
13 RAMACHANDRAN, V. S. and William HIRSTEIN. The Science of Art: A Neurological Theory of Aesthetic Experience. In GOGUEN, Joseph A. (ed.) Art and the Brain: Journal of Consciousness Studies. Special edition, June 1999, vol. 6.

14 An antology of works collected by Nicholas Mirzoeff is dedicated to the concept of perceiving not art, but visual culture, MIRZOEFF, Nicholas. The Visual Culture Reader. 2nd ed. London, New York, 2009.

15 ZEKI, Semir and Matthew LAMB. The Neurology of Kinetic Art. Brain, 1994, no. 117, pp. 607-636.
}

"imaginary debate" which started during the 1970s and lasted for over thirty years between Stephen Kosslyn and Zenon Pylyshyn ${ }^{16}$ - led, in effect, to the so-called Kosslyn's Theory of Imagery. ${ }^{17}$ His theory concludes that the previously applied divisions into visual perception, imagination and consciousness as separable areas are no longer permitted. ${ }^{18}$ This assumption was critical not only to artistic studies but also to aesthetics. In view of this, Kosslyn was not only transforming the methodological basis for the study of art assumed in the $20^{\text {th }}$ century, but he was also reaching to the roots of the traditional depiction of images (or, in other words, works of art) - outdated by then according to neuroscientists. Their descriptions had for centuries included terms such as "form" and "content" which generally correspond to the "seeing" and "understanding" division. This dichotomy appeared to be somewhat evident not only in theoretical and critical writings as well as in literature-like treaties on art, but also in artistic studies since the turn of the $19^{\text {th }}$ and $20^{\text {th }}$ centuries. Although $20^{\text {th }}$ century philosophy and art history methodologies laid out many paths and ways of initiating "the understanding" of artistic works and their interpretation - starting with "straightforward" formalisms, iconologies and studies of cultural contexts through methods drawn from linguistic and cultural theories (such as semiotics, hermeneutics, and deconstruction), to structuralism, post-structuralism, or gender studies - this dichotomy, while

\footnotetext{
16 PYLYSHYN, Zenon Walter. Mental Imaginary. In Search of Theory. Behavioral and Brain Sciences, 2002, no. 25, pp. 157-238.

17 KOSSLYN, Stephen M. Mental Images and the Brain. Cognitive Neuropsychology, 2005, vol. 22, pp. 333-347.

18 See: FRANCUZ, Piotr. Teoria wyobraźni Stephena Kosslyna. Próba reinterpretacji, [Stephen Kosslyn's Theory of Imagery. An Attempted Interpretation]. In FRANCUZ, Piotr (ed.). Obrazy $w$ umyśle [Images in the mind]. Studia nad percepcja i wyobraźnia. Warszawa: Scholar, 2007, pp. 149-189.
} 
carefully circumvented and avoided in a multitude of ways, did not disappear from colloquial speech and our way of thinking. On the contrary, looking at art from the first decade of the $21^{\text {st }}$ century in its global, world-wide dimension of diversity has intensified this issue. This initial image - this "original" which was the carrier of form nearly ceased to exist while we - in a flood of copies (or simulacra as Jean Baudrillard would have put it) - are left alone with the subject matter (often precipitously taken as "meaning") of the messages.

Today, when we read writings by Jacques Lacan, Roland Barthes, Michele Foucault, Jacque Derrida, Jean François Lyotard, and especially those by Julia Kristeva, Patricia Methews or David Halperin from the perspective of the last two decades of neuresthetic - evolution we feel fear, fear that is hidden, yet founded in a unilateral approach. It is fear of the effects of drowning in an expanse of conflicting interpretations. A term which practically borders on this abandonment of the significance of the object's form is "narration". Not without malice do I place it in quotations marks - it was overused without moderation at the end of the $20^{\text {th }}$ century, giving birth to another problematic child, namely the concept of "criticality" of works of art, events, and artistic institutions in relation to events, activities and artistic implementations. Art merged with life which does not mean, however, that every manifestation of life became art. Luckily, researchers and art historians such as John Onians, Norman Bryson or Warren Neidich turned here towards the past noticing in aesthetic and art theory history the very questions asked in the days by Plato and Aristotle, William Hogarth, Immanuel Kant or Heinrich Wölfflin which had been patiently waiting to be revisited and revived.
John Onians' Neuroarthistory ${ }^{19}$ served as a turning point in this retrospection of the history of art, philosophy and European aesthetics. The summary of his 30 year-long research was published in 2007. The author inserted the following dedication: "For the art historians of the future who have the courage also to be neuroarthistorians." Aside from a short, merely 17-page-long introduction, the book consists of a selection of short source text fragments along with Onian's slightly longer commentaries. Its chapters successively are dedicated to the opinions of art and perception of: Aristotle, Pliny the Elder, Apollonius of Tyana, Alhazen (Ibn-al-Haytham), Alberti, Leonardo, Hogarth, Burke, Montesquieu, Winckelmann, Kant, Marx, Ruskin, Pater, Taine, Vischer, Göller, Wölfflin, Riegel, Freud, Dewey, Herskovits, Gombrich, Baxandall, and Zeki. The configuration of texts - as can be seen without hesitation - is an unveiling of the ongoing suspicions of many thinkers and artists as to the inseparability of form and meaning of a work of visual art as well as their combined influence on the process of perception. What is more is the texts' effect on the changes taking place in our brain under the influence of extraordinary artistic objects. Reading Onians' book unveils the magnitude of art's influence on the civilizational changes in our entire surroundings which are caused by the formation of many perceptive skills and conscious reflexions as important as, for instance, the shaping of the discernment of illusion of space within the frame of a flat picture.

The author's conclusions and observations, nevertheless, reach further than merely the concept of perceiving the unity of form and meaning. Onians emphasizes that the power of neuroscience involves the fact

19 ONIANS, John. Neuroarthistory. From Aristotle and Pliny to Baxandall and Zeki. New Haven, London: Yale University Press, 2007. that "neuroscience also made it not just possible, but necessary, to bring back together things long treated as separate - the mind and the body, the sensory system and the motor system, cognition and the viscera." ${ }^{20} \mathrm{He}$ also repeatedly quotes other authors, such as for example Norman Bryson. "[Poststructuralism] commits itself to an intensely cognitive point of view. Feeling, emotion, intuition, sensation - the creatural life of the body and of the embodied experience tend to fall away, their place taken by an essentially clerical outlook that centers on the written text," 21 Bryson writes, listing concepts such as: text, discourse, code, and meaning, the use of which, according to him, would have led to a crisis of the artistic studies and the loss of contact with that which in the works of art most stimulates our development namely their form full of meanings. In this sense, the neurohistory of Onians' art has become a proposition for a re-examination of nearly the entire artistic activity of different cultures in order to find lost trajectories and return to the paths of interest, or simply the corporally sensual fascination with some works of art.

Another critical publication appeared in 2007 which was dedicated to the evaluation of the state of the research of arts and culture. What I mean here is the synthetic depiction by the philosopher and critic Roger Scruton entitled Culture Counts: Faith and Feeling in the World Besieged. ${ }^{22}$ Although he writes from the position of a sociologist and cultural philosopher, he comes to similar conclusions as Bryson or Onians. For Scruton, the "healing of the eye" will take place in the

\footnotetext{
20 Ibidem, p. 4.

21 Ibidem, p. 1. BRYSON, Norman. Introduction. In NEIDICH, Warren. Blow-up: Photography, Cinema and the Brain. New York: D.A.P./Ucr/California Museum of Photography, 2003, p. 11.

22 SCRUTON, Roger. Culture Counts: Faith and Feeling in the World Besieged. New York: Encounter Books, 2007.
} 
$21^{\text {st }}$ century as a result of regaining consciousness and returning to those art forms which respect our "nature", i.e., to such forms which allow for a multi-dimensional and multi-functional way of sensing and reacting. Despite the fact that Onians' and Scruton's books were written independently, both authors refer to texts by the same famous philosophers, estheticians and artists both suggesting re-reading their writings. It turns out that Burke's Treatise on the Sublime and the Beautiful, or Kant's Critique of Judgment bring the answers given long ago as to how we should "yield ourselves to" the influence of paintings, sculptures, or architectural works in order to connect esthetic and emotional values with a corporal experience of pleasure.

The construction of a new neuroaesthetics edifice would not have been possible, however, if not for its roots in the sciences of biology and the psychology of perception. We have Semir Zeki to thank for building a bridge between the neurophysiology of perception and artistic practice. Zeki was the co-creator and one of the first users of the imaging method of the study of the functional activities of the brain with the application of magnetic resonance (called fMRI - functional magnetic resonance imaging), while previously to that he applied positron tomography.

Since the mid 90s, Zeki - rather than lecturing in medical institutions or neurophysiological institutes - began lecturing more frequently in museums. Through a series of lectures in Tate Gallery, later continued in Musée d'Orsay, Gemälde Galerie in Berlin, and at the Getty Museum in Los Angeles (2003) - along with social and professional connections within the circle of the former students and seminarists of Ernst Gombrich, Zeki found his way to museologists and artists. Zeki's observations and research reached the group of museologists and artists who in their practice were interested in development and perception of art shown in different types of museums, while in their theory their interest was piqued by the particular behaviour of people and the change in their perception when they were inside museums. It was specifically these "anomalies" of reactivity which took place only within museum contexts that attracted Zeki's attention to such a degree that he himself became curator of exhibitions in 2003, and became involved both conceptually and practically in the organization of experimental expositions in museums (such as for example, Colore et Cervello - Colour and the Brain in Casa Rusca in Locarno, 2003). Zeki's last book - Splendors and Miseries of the Brain. Love, Creativity, and the Quest for Human Happiness ${ }^{23}$ - constitutes a summary both of his observations related to the process of analytical and thoughtful seeing, and the influence of the mechanisms determining our perceptions and consciousness - equally on the creation of the world around us as well as on its perception.

For Zeki, Kant was the initiator of a neuronal approach to art. Furthermore, the subsequent development of phenomenology was proof of the over two-centuries-long studies of the internally forming phenomenon which is comprised of artistic occurences in their form and content, or symbolic dimension. Zeki describes that which thus far in the history of art was expressed through the categories of style, tendency or avant-garde changes - and which from the perspective of neuroaesthetics constitutes a natural chain of evolution of our brain and our need for an idea of the world that is increasingly more sophisticated and distant from its

\footnotetext{
23 ZEKI, Semir. Splendors and Miseries of the Brain. Love, Creativity, and the Quest for Human Happiness. Chichester: Wiley-Blackwell, 2009.
}

objective reality. This evolution provides more room for imagination and internal vision (the result of centuries-long training of a visual buffer ${ }^{24}$ ). It leads towards "imagined pictures" and causes those "internal images" of artists to be perceived and understood as "pictures" also by other observers. Reading Zeki, what is unveiled as something natural in its entirety is the codification of non-objective art, which does not imply a "lack of its significance". In this context, the writings by Wassil Kandinsky or Kazimierz Malewicz enlighten their reader to the artists who have been "neuroresearchers" since time immemorial. Their role consisted, and still does, of a continuous raising of the bar in the process of rational perception. Many films have been produced over the last two decades where their content consists of computer-animated worlds - pictures composed of well-known borrowings, real elements (often "taken" from the iconosphere of ancient or medieval art) and magically literary visions, as well as "abstract" effects (such as transitions of colours, lights and movement of non-objective shapes) which without any problems are today perceived and commented on by their viewers.

Zeki calls these states "Higher Levels of Ambiguity" 25 and anaLyses them based on the examples of

\footnotetext{
24 "A visual buffer [acc. to Kosslyn's theory] is a functional structure which in a model, represents the group of primary and secondary visual fields which can be found in the occipital lobe of the cerebral cortex ... . Both during perception and imagining, the buffer serves the purpose of initially organizing the visual material, or to put it in David Marr's words, to create an initial sketch of the picture. Kosslyn compares the visual buffer to a board or a dynamic display on which pictures are continually changing due to external stimulation" - as quoted in: FRANCUZ, Piotr. Teoria wyobraźni Stephena Kosslyna. Próba reinterpretacji, [Stephen Kosslyn's Theory of Imagery. An Attempted Interpretation]. In FRANCUZ, Piotr (ed.). Obrazy $w$ umyśle [Images in the mind]. Studia nad percepcja i wyobraźnia. Warszawa: Scholar, 2007, pp. 156-157. David Marr's work mentioned by Francuz entitled Vision, New York 1982

25 ZEKI, Semir. Splendors and Miseries of the Brain. Love, Creativity, and the Quest for Human Happiness. Chichester: Wiley-Blackwell, 2009,
} p. 87. 
ancient art. An already classic example of such an analysis is the description of the perception of Johannes Vermeer's Girl with a Pearl Earring (around 1664, Mauritshuis, Haag). What is superimposed onto seeing the portrait of the young woman during the process of perception is the inevitable "emotional" identification of the depicted figure, which determines a suitable mental registration of the image (question: what feelings does the depicted woman express?). In short - we will read and remember The Girl with the Pearl Earring in such a way in which we interpret her emotional message which is inseparably linked to the layer of paint, frame and meaning. We hesitate, however, at times seeing her as inviting, at other times as distant, erotically charged while chaste, resentful but pleased, as Zeki observes. Vermeer - as a conscious neuroresearcher - does not make this task any easier for us. "The genius of Vermeer is that he does not provide an answer but, by a brilliant subtlety, manages to convey all the expressions, although the viewer is only conscious of one interpretation at any given moment," ${ }^{26}$ writes Zeki. This insecurity causes the perceiver to imbue the viewing of the painting with a much greater mental effort because no determination of emotions is final.

\section{Neuromuseology}

\section{Zeki's description of Vermeer's}

\footnotetext{
26 Ibidem, p. 87. The description of experiencing "one sensation" in a given moment despite awareness that they can be different experiences resembles in the process of visual perception a so-called "double picture" or "double vision", compositions made up of different single objects seen, however, in the whole arrangement as the representation of something different. As an example of "double vision" often referred to are paintings by Arcimbold - portraits where the face is made up of, for instance, several kitchen utensils. This phenomenon was a separate section of the exhibition: Perspektywa, iluzja, iluzjonizm [Perspective, Illusion, and Illusionism] at the National Museum in Warsaw in 1981; FOLGA-JANUSZEWSKA, Dorota. Perspective, Illusion, Illusionism: Exhibition Catalogue. Warsaw: Muzeum Narodowe w Warszawie/National Museum in Warsaw, 1981. Creating ambivalence of perception, as Zeki observes, is one of the intriguing features of works of art.
} painting augmented by quotations from Schopenhauer's writings becomes an inspiring introduction to the concepts with which we from time to time are dealing with since museums have become institutions.

It is no coincidence that the great Epoch of Museums in Europe begins at the same time as the publishing of Kant's works $\left(1764^{27}-1790^{28}\right)$. Onians points out that owing to the stipulation of the apriority of time and space, Kant has made us aware that "the integration of genius, soul and imagination can lead to a production of works that produce 'much thoughts' yet not a thought that can be represented in language." 29 At the same time, he directed a stream of deliberations at the problem of cohesion of mental and sensual perception, which in essence is the subject matter of modern-day neuroaesthetics.

From the point of view of museum history, the reason for their foundation originated from the need to turn private collections (intentionally amassed groups of objects ${ }^{30}$ ) into areas of esthetic, intellectual, and emotional experiences. Museums were thus the first areas where, upon rejecting utilitarianism or ideas of usefulness of a collection for political gain, "areas of reflection" were being constructed. In these places, an observer could -

while detached from religious, courtly or bourgeois rituals - "become immersed" in these artificially arranged worlds. To some degree, museums understood in such a way were derived from the theatre. In such a context, the collections constituted the stage design and the viewers became actors who performed for themselves or for others plays which were partially pre-scripted while partially improvised.

In the second half of the $18^{\text {th }}$ century, a new type of museums was born, namely great museums of art, ${ }^{31}$ artistic agglomerations, the existence of which was, (in contrast to scientific museums or cabinets of curiosities) not exclusively linked to educating. Art museums were to take the visitor to a state of pleasure derived from an aesthetic experience (characterized - as we would say today - as strictly neuronal). These museums were domains of the "pursuit of pleasure". Certainly they did thus have an educational dimension because it was there that cerebral evolution was expedited as it was simultaneously confronted with picture, imagination and consciousness.

Essentially non-utilitarian creatures had sprung up in Europe. The collections bequeathed to museums lost their dimension of material value (because they basically were never sold). What is more, museums did not serve a receptive function unlike residences - so the works of art gathered within them ceased to be characterized as "utilitarian art" (for example, military equipment in museums was no longer used in battles, crystal goblets - for drinking, and beautiful fabrics - to decorate rooms). A new goal appeared: constructing an area of experiences, a place for aesthetic sensations,

29 ONIANS, John. Neuroarthistory. From Aristotle and Pliny to Baxandall and Zeki. New Haven, London: Yale University Press, 2007, p. 81.

30 On defining collections and their intentionality see: POMIAN, Krzysztof. Collectors and curiosities. Paris-Venice 16th-18th centuries. Paris, 1987.
31 See: MCCLELLAN, Andrew. The Art Museum from Boullée to Bilbao. Berkeley, Los Angeles: University Of California Press, 2008. 
and the "reading of paintings" for pleasure.

The $19^{\text {th }}$ century, along with the philosophy of romanticism, complemented the idea of museums with one more element, namely, that of a need for illusion and deep emotions. The assembled collections were no longer expected to be beautiful and ancient, but to a larger extent they were to provide sensations which nature - despite its great potential - failed to do. What happened in museums was a real transformation of "recorded history" into emotional history. The $19^{\text {th }}$ century was an era of "national museums" - characterized by a need for an emotional connection with history and assigning to the forms of particular objects a symbolic dimension. The phoneomena of national identity and the feeling of belonging to a country's structures found their reflection and constitution in tendentiously amassed collections. Their "artificiality" was physiological. In a material form, they addressed particular spiritual and mental needs and gave them an almost carnal dimension. At the end of the $19^{\text {th }}$ century, museums were - next to the train station, town or city hall and tavern - the most important locations in the city. They were part of the public sphere. They became a given. This physiological aspect of creating museums remains practically undescribed to this day. The tendency to give every venture a "higher" dimension (exclusively spiritual) brought about a crisis of this institution in the $20^{\text {th }}$ century. The unaddressed relationship between the "natural artificiality of a museum" and a need for the evolution of perception led to many misunderstandings.

It is quite difficult to describe in one short article the development of the concepts of the functions and aims which were and are at the core of museums. Neuronal aesthetics pro- vides support which stems from the observation of behaviours and the perceptual process. This support is based on providing an incentive to revise certain goals at the beginning of the $21^{\text {st }}$ century and thereafter, to adjust the ways of organizing museums. It is exactly within this scope that neuromuseology can intimate new and interesting solutions for the viewer.

\section{Application of neuroscientific} achievements in museums should be, however, preceded by a reflection on seemingly obvious concepts and questions about the definition, place, meaning and goal of the operation of such institutions. First, the fundamental question - what is a museum? - should be asked. The answer is not as simple as might be suggested by lexical considerations. In this case, we are aware that the concept behind the question of "what?" may simultaneously include a "how?".

\section{A museum is a living context, or area where objects interact with perceivers and these perceiv- ers "create" objects during the perceptual process. Material and/} or immaterial objects gathered in a museum are chosen counsciously ${ }^{32}$ and are used to create a perceptual - visual, sonic, or multi-senso$\mathrm{ry}^{33}$ - arrangement. In this sense, every museum is a "screenplay" for a performance - an intentional message in which the shape (pictorial, sonic, or received through the sense of touch) of a showpiece establishes itself in a defined space with reference to other shapes.

\footnotetext{
32 Obviously, there are storage-museums of random objects, but I propose not to call these "intentional museums".

33 Since the beginning of the 20th century, a debate has been in progress over the motivating factors of these collections: artistic, content-related, economic, or maybe „neuronal”, i.e. such where visual subconscious coupled with theoretical knowledge is in search of "complementary objects". See: chapter 4 of: SPALDING, Julian. The Poetic Museum. Reviving Historic Collections. Munich, London, New York: Prestel Publishing, 2002, p.51-63.
}

A museum is thus an "entirety" within which objects have their position (visual, historic, symbolic, and sensory - perceived globally). A change of position may have an effect not only on a change in the perception of these objects, but even on their complete removal from the field of memory. A museum is not "empty space" but in itself, it has a defined shape and form - an area which has a powerful character. The welfare of objects within it depends on its space; the objects are there, they levitate and change - depending on their position - their individual meaning. The museum determines the existence of objects. I deliberately speak here not of an exhibit, or exposition, but of the entire museum because the existence of collections, their acquisition, their display, and their presentation requires a multi-step process which leads to "conferring space and meaning". A museum employee (curator) who receives an object into the collection and enters it into the inventory is the first link on a choices and emplacements chain. Each work of art or any other object which is admitted to the museum becomes an atom that interacts with the others. We know of interesting examples where an acquisition (in order to supplement a collection) of a sculpture or painting- its addition to the collection - spawned a new perceptual realm, raising the expression and meaning of both hitherto existing objects as well as that of the added one.

The welfare of the viewer depends on museum space. Once we become aware of the results of neuroesthetic research it will become evident that a museum is a type of a perceptual laboratory. The organization of an exhibition which consists of hanging paintings, arranging objects, labelling them, adding multimedia presentations, creating transitions between them, their entrances and exits, and curtain falls - is a way of finding new solu- 
tions which we do not experience in "practical" reality. One says of museum employees that they "have and eye" - an ability to find such relations between objects (paintings, sculptures, and articles) which increase the values of the exhibits and give their viewers pleasure.

This ability determines the creation of a new "exploratory" context - an ability, at times innate, and at times formed over years, is nothing if not a neuronal shaping of exhibition space. Intuition, whereas, which we often hear about, emerges as being a visual experience put into practice.

Each object (for instance, a work of art) is "immersed" in a museum. This immersion deforms, changes, refines or debases objects. In a museum, they become cogwheels within a new perceptual mechanism. It may be that artists aware of this aspect had a very emotional attitude towards museums. On one hand, they wanted their works of art to find their way to museums, while on the other - like futurists they proclaimed the end of these institutions, their ruin, and devastation. Artists themselves have been creating museums for centuries. Rudolph Bauer's ideas - implemented in the first Museum of Abstract Art (Geistreich, 1926-1928) in Berlin or the Museum of Futurism in Rovereto organized by Fortunato Depero were excellent examples thereof. Studies of the branch of museology which proposes to treat a museum as an area supporting the evolution of the perceptual system should have been conducted there.

If we apply neuroesthetic experiences in museology more widely, museums of the $21^{\text {st }}$ century will not merely be repositories of the past, but they will become the most important areas of multisensory education. They will be places that stimulate the development of perception, understanding, and cultural intelligence. We will slowly begin to realize that in the world around us, many sectors "producing" tangible goods are nearing their end the great era of objects is nearly over. What is beginning is a new epoch of imagined, virtual activities, scenarios which use historical artefacts (collections, antologies) creatively in order to provoke the world to a visual (also on a neuronal dimension) revolution. In this sense, the museum must confront neuroesthetic experiences. ${ }^{34}$ Studies of the changes taking place in our perception and in our understanding of our surroundings should be conducted in laboratories called museums.

Having concluded that the museum is the specific context of perception of all forms of images, we should remember that this kind of interest and this point of view is not born nowadays. It was present from Antiquity and analysed by several scientists and theoreticians. An interesting view to the fascination of brain activities in art was presented at the interesting exhibition Obrazy mysli - mysl v obrazech, organized in the Moravská galerie v Brně in 2011. The catalogue is one of the most valuable résumé of what was achieved in contacts between medicine and art on the field of „proto-neuroaesthetic” during past four centuries. ${ }^{35}$

\section{BIBLIOGRAPHY}

ARNHEIM, Rudolf. Art and Visual Perception: A Psychology of the Creative Eye. Berkeley, Los Angeles, 1954.

34 See also: FOLGA-JANUSZEWSKA, Dorota. The Brain in the Museum. In SZMELTER, Iwona (ed.). Innovative Approaches to the Complex Care of Contemporary Art. Warsaw, London: Archetype Publications, 2012, pp. 66-73; FRANCUZ, Piotr. Imagia. W stronę neurokognitywnej teorii obrazu. Lublin: Wydawnictwo KUL, 2013; FOLGA-JANUSZEWSKA, Dorota and Elżbieta GRYGIEL (eds.). Edukacja $w$ muzeum rzeczywistym i wirtualnym. Kraków: Universitas, 2013. Series Muzeologia.

35 KESNER, Ladislav and Colleen M. SCHMITZ et al. Obrazy mysli - mysl v obrazech. Brno: Moravská galerie v Brně, 2011.
ARNHEIM, Rudolf. Visual Thinking. Berkeley: University Of California Press, 1969. ISBN 978-0-520-01378-0.

BAXANDALL, Michael. Painting and Experience in Fifteenth-Century Italy: A Primer in the Social History of Style. Oxford: Oxford Paperbacks, 1979. ISBN 978-0-19$-881329-3$.

BELTING, Hans. Place of reflection or place of sensation? In NOEVER, Peter (ed.). The Discursive Museum. Vienna: MAK, 2001, pp.77-78. ISBN 978-3-7757-1140-1.

BLAKEMORE, Colin. The Mind Machine. London: BBC Books, 1988. ISBN 978-0-563-20646-0.

BOUQUET, Mary (ed.). Academic Anthropoly and the Museum. Back to the Future. Oxford, New York: Berghahn Books, 2001. ISBN 978-1-57181-321-3.

BOUQUET, Mary. Museums. A Visual Anthropology. London, New York: Berg, 2012. ISBN 978-1-84520-812-7.

BRYSON, Norman. Introduction. In NEIDICH, Warren. Blow-up: Photography, Cinema and the Brain. New York: D.A.P./ Ucr/California Museum of Photography, 2003, p. 11. ISBN 978-1-891024-80-1.

CARBONELL, Bettina Messias. (ed.). Museum Studies. An Anthology of Contexts. $2^{\text {nd }}$ ed. Chichester: Wiley-Blackwell, 2012. ISBN 978-1-4051-7381-0.

CHANGEUX, Jean-Paul. Art and Neuroscience. Leonardo, 1994, vol. 27, no. 3, pp. 189-201. ISSN 0024-094X.

CHANGEUX, Jean-Pierre. L'homme neuronal. Paris: Fayard, 1983. ISBN 978-2-213-01247-6.

COLLINS, Desmond M. and John ONIANS. The Origins of Art. Art History, 1978, vol. I, pp. 1-25. ISSN 1467-8365.

CRANE, Susan A. Museums and Memory. Stanford: Stanford University Press, 2000. ISBN 978-0-8047-3565-0.

CRIMP, Douglas. On the Museum's Ruins. Cambridge: MIT Press, 1993. ISBN 978-0-262-53126-9.

FOLGA-JANUSZEWSKA, Dorota. Concepts of Space in Contemporary Art: Exhibition Catalogue. Warsaw: Muzeum Narodowe $\mathrm{w}$ Warszawie/National Museum in Warsaw, 1984.

FOLGA-JANUSZEWSKA, Dorota. Perspective, Illusion, Illusionism: Exhibition Catalogue. Warsaw: Muzeum Narodowe w Warszawie/National Museum in Warsaw, 1981.

FOLGA-JANUSZEWSKA, Dorota. The Brain in the Museum. In SZMELTER, Iwona (ed.). Innovative Approaches to the Complex Care of Contemporary Art. Warsaw, London: Archetype Publications, 2012, pp. 66-73. ISBN 978-1-904982-81-4. 
FOLGA-JANUSZEWSKA, Dorota and Elżbieta GRYGIEL (eds.). Edukacja w muzeum rzeczywistym $i$ wirtualnym. Kraków: Universitas, 2013. Series Muzeologia. ISBN 978-83-242-2356-5.

FRANCUZ, Piotr. Imagia. $W$ stronę neurokognitywnej teorii obrazu. Lublin: Wydawnictwo KUL, 2013.

FRANCUZ, Piotr. Teoria wyobraźni Stephena Kosslyna. Próba reinterpretacji, [Stephen Kosslyn's Theory of Imagery. An Attempted Interpretation]. In FRANCUZ, Piotr (ed.). Obrazy $w$ umyśle [Images in the mind]. Studia nad percepcja i wyobraźniq. Warszawa: Scholar, 2007, pp. 149-189. ISBN 978-83-7383-246-6.

GOMBRICH, Ernst H. The Sense of Order. A Study in Psychology of Decorative Art. Ithaca: Cornell University Press, 1979. ISBN 978-0-7148-1732-3.

GRENIER, Catherine. La fin des musées? Paris: Editions du Regard, 2013. ISBN 978-2-84105-309-4.

HENNING, Michelle. Museums, Media and Cultural Theory. Maidenhead: OUP, 2006. ISBN 978-0-335-21419-8.

KANT, Immanuel. Beobachtungen über das Gefühl des Schönen und Erhabenen. North Charleston: Createspace, 2015. ISBN 978-

$$
\text { -1-5141-0848-2. }
$$

KANT, Immanuel. Kritik der Urteilskraft. Lenox: Hardpress Publishing, 2013. ISBN 978-1-313-57445-7.

KESNER, Ladislav and Colleen M. SCHMITZ et al. Obrazy mysli-mysl v obrazech. Brno: Moravská galerie v Brně, 2011. ISBN 978-80-7027-239-8.

KOWALSKA, E. and E. URBANIAK (eds.). Muzeum XXI wieku. Teoria i praxis. Materiały z sesji naukowej, organizowanej przez Muzeum Początków Państwa Polskiego i Polski Komitet Narodowy ICOM, Gniezno, 25-27 listopada 2009 roku. Księga pamiątkowa poświęcona profesorowi Krzysztofowi Pomianowi [online]. Gniezno: Muzeum Początków Państwa Polskiego, 2010 [cit. 2016-0515]. Available from www: <http://www. muzeumgniezno.pl/fotki/files/files/publikacje/muzeum21w.pdf $>$.

KOSSLYN, Stephen M. Mental Images and the Brain. Cognitive Neuropsychology, 2005 , vol. 22, pp. 333-347. ISSN 0264-3294 .

MAIRESSE, François. Le Musée, temple spectaculaire. Une histoire du projet $\mathrm{mu}$ séal. Lyon: Pul, 2003. ISBN 978-2-7297-0700-2.

MALRAUX, André. Le Musée imaginaire. Paris: Galimard, 1947.

MCCLELLAN, Andrew. The Art Museum from Boullée to Bilbao. Berkeley, Los
Angeles: University Of California Press, 2008. ISBN 978-0-520-25126-7.

MESSAGE, Kylie. New Museums and the Making Culture. Oxford, New York: Berg, 2006. ISBN 978-1-84520-454-9.

MIRZOEFF, Nicholas. The Visual Culture Reader. $2^{\text {nd }}$ ed. London, New York, 2009. ISBN 978-0-415-78262-3.

ONIANS, John. Neuroarthistory. From Aristotle and Pliny to Baxandall and Zeki. New Haven, London: Yale University Press, 2007. ISBN 978-0-300-12677-8.

POMIAN, Krzysztof. Collectors and curiosities. Paris-Venice 16th-18th centuries. Paris, 1987.

PYLYSHYN, Zenon Walter. Mental Imaginary. In Search of Theory. Behavioral and Brain Sciences, 2002, no. 25, pp. 157-238. ISSN 0140-525X.

RAMACHANDRAN, V. S. and William HIRSTEIN. The Science of Art: A Neurological Theory of Aesthetic Experience. In GOGUEN, Joseph A. (ed.). Art and the Brain: Journal of Consciousness Studies. Special edition, June 1999, vol. 6. ISBN 978-0-907845-45-4.

SCRUTON, Roger. Culture Counts: Faith and Feeling in the World Besieged. New York: Encounter Books, 2007. ISBN 978-1-59403-194-6.

SMITH CHURCHLAND, Patricia. Neurophilosophy: Toward a Unified Science of the Mind. Cambridge: Bradford Book, 1989. ISBN 978-0-262-53085-9.

SPALDING, Julian. The Poetic Museum. Reviving Historic Collections. Munich, London, New York: Prestel Publishing, 2002. ISBN 978-3-7913-2678-8.

VARELA, Francisco, Evan THOMPSON and Eleonor ROSCH. The Embodied Mind: Cognitive Science and Human Experience. Cambridge: MIT Press, 1991. ISBN 978-0-262-72021-2.

VERGO, Peter (ed.). The New Museology. London: Reaktion Books, 1989. ISBN 978-0-948462-03-0.

ZEKI, Semir. Inner Vision. An Exploration of Art and the Brain. Oxford: Oxford University Press, 1999. ISBN 978-0-19-850519-8.

ZEKI, Semir. Splendors and Miseries of the Brain. Love, Creativity, and the Quest for Human Happiness. Chichester: Wiley-Blackwell, 2009. ISBN 978-1-4051-8557-8.

ZEKI, Semir and Matthew LAMB. The Neurology of Kinetic Art. Brain, 1994, no. 117, pp. 607-636.

\section{DOROTA FOLGA-JANUSZEWSKA}

Muzeum Pałacu Króla Jana III w Wilanowie, Polska

dfolgajanuszewska@muzeum-wilanow.p

Born 1956 in Warsaw, professor at the Academy of Fine Arts in Warsaw, Head of Theory Department, Faculty of Graphic Art, deputy director at the The King Jan III Palace Museum in Wilanow, Warsaw.

President ICOM-Poland, president MOCO ICOM, member of AICA.

Art historian, art critic, museologist; 2010-2012 director of the Institute of Museology, Wyszynski University in Warsaw. Founder of the museological studies. Member of the International Print Triennial Society in Cracow, presently honorary member. Juror in many prints and contemporary art competitions.

Worked at the National Museum in Warsaw 1979-2008 (curator at the Contemporary Print and Drawing Department, 1995-2007 - director for collection, research program and education, 2007-2008 general director). From 1986-2000 - lecturing at Warsaw University (Portugal art, museology). 2002-2005 Director of the Young Art Prize and Competition of the President of the Republic of Poland. From 2005 member of Independent Group of Experts, EU Council and member of working groups in the EU program Mobility of Collection. Scholarship and Fellowship: Centro di Studi do Archittetura Andrea Palladio, Vicenza; The Scholarship of the Government of Portugal; Indira Gandhi National Centre for Arts, New Delhi; Institut fur die Wissenschaften vom Menchen, Wien; Goethe Institut, Munchen; Klee-Stifftung Bern - Pro Helvetia, Bern.

Publications: ca 340 books, catalogues, curator of 54 exhibitions.

Narodila se v roce 1956 ve Varšavě. Je profesorkou na Akademii výtvarných umění ve Varšavě, vedoucí Katedry teorie na Fakultě grafiky, zástupkyní ředitele Muzea 
královského paláce Jana III. ve Wilanowu ve Varšavě.

Je také prezidentkou ICOM v Polsku, Prezidentkou MOCO ICOM, členkou AICA.

Historička umění, umělecká kritička, muzeoložka; 2010-2012 ředitelka Ústavu muzeologie na Wyszyńského univerzitě ve Varšavě. Zakladatelka studia muzeologie. Členka Společnosti pro Mezinárodní trienále grafiky ve Varšavě, v současnosti čestná členka. Porotkyně v mnoha soutěžích grafiky a soudobého umění.

Pracovala v Národním muzeu ve Varšavě v letech 1979-2008 (kurátorka v Oddělení soudobé grafiky a kresby, 1995-2007 - ředitelka pro sbírky, výzkumný program a vzdělávání, 2007-2008 generální ředitelka). V letech 1986-2000 přednášela na Varšavské univerzitě (portugalské umění, muzeologie). 2002-2005 ředitelka Ceny a soutěže mladých umělců pod záštitou prezidenta Polska. Od roku 2005 je členkou Nezávislé skupiny expertů při Radě EU a členkou pracovních skupin v rámci evropského programu Mobilita sbírek.

Stipendia a stáže: Centrum architektonických studií Andrey Palladia, Vicenza; Stipendium portugalské vlády; Národní centrum umění Indíry Gándhíové, Nové Dillí; Institut pro vědy o člověku, Vídeň; Goetheho institut, Mnichov; Nadace Paula Kleeho Bern - Pro Helvetia, Bern.

Publikace: cca 340 knih, katalogy, kurátorka 54 výstav. 